\title{
Assessment of Seasonal and Vegetational Variations in the Airborne Bacterial Concentration of the Urban Forest Park: A Case Study in Hunan, China
}

\author{
Zhenni Liao \\ Huijuan Xu \\ South China Agricultural University \\ Jiaojiao Ma \\ South China Normal University \\ Maojuan Li \\ Chenzhou Institute of Forestry \\ Caisheng He \\ Chenzhou Institute of Forestry \\ Qiongrui Zhang \\ South China Normal University \\ Songjun Xu ( $\nabla$ xusj@scnu.edu.cn ) \\ South China Normal University
}

South China Normal University; Chenzhou Institute of Forestry https://orcid.org/0000-0001-9692-5291

\section{Research Article}

Keywords: Urban forest park community, Vegetation specie, Forest airborne bacteria, Concentration, Antimicrobial capacity, Influencing factors

Posted Date: August 17th, 2021

DOI: https://doi.org/10.21203/rs.3.rs-736043/v1

License: (c) (i) This work is licensed under a Creative Commons Attribution 4.0 International License. Read Full License 


\section{Abstract}

It is important to investigate bacterial air quality in urban forest parks because tree bacteriostasis practices are being increasingly advocated as measures to improve the air quality and public-health in urban green spaces around the world. The aim of the present study was to quantitatively investigate airborne bacterial concentration levels based on field measurements in every season in five selected forest communities and the uncovered space in an urban forest park, as well as the effects of several factors on the culturability of airborne bacteria. Results suggested that the airborne bacterial levels of all forest communities reached the clean air quality standard with regard to the airborne bacteria content, with the highest bacteria concentrations in the uncovered space $\left(1658 \pm 1298 \mathrm{CFU} / \mathrm{m}^{3}\right)$, and the lowest in the mixed community $\left(907 \pm 567 \mathrm{CFU} / \mathrm{m}^{3}\right)$. The temporal distribution analysis showed that the most airborne bacteria were concentrated in summer, as well as in the morning and afternoon. The bacteriostatic rates of the mixed community were significantly different with seasonal variation $(\mathrm{p}<0.05)$. Spearman's correlations revealed that the bacterial concentration was significantly positively correlated with the season, wind speed (WS), temperature (T), ultraviolet light (UV), negative air ion (NAI) and total suspended particles (TSP) (p®0.05), but significantly negatively correlated with the forest community type $(\mathrm{p}<0.05)$. WS, UV, NAI, TSP and PM2.5 showed significant effect on airborne bacterial concentration in a multiple linear regression model $(p<0.05)$. Overall, the selection of tree species plays a key role in shaping the forest structure and improving air quality, and the urban forest highlights key priorities for future efforts towards a cleaner, healthier, and more diverse regional forest environment.

\section{Introduction}

With rapid social development and urbanization processes, human health risks increase due to lifestyle-related stress and surrounding environment deterioration, and the amount of pathogenic bacteria related to human diseases in the air keep increasing. Since the development of the concept of "forest bath" as a therapy in the 2000s, many studies using a variety of methodologies, have been conducted to verify the effect of forest environments on encouraging physical recreation and promoting physiological restoration (Bielinis et al. 2018; Joung et al. 2015; Ochiai et al. 2015; Song et al. 2017; Yu and Hsieh 2020). The assessment of the various environmental factors (airborne microbes, biogenic volatile organic compounds (BVOCs), negative air ion (NAI), air pollutants, particulate matter (Broeckx et al.), and etc.) of the forest park represent one of the biggest concerns for public health (Guo et al. 2013; Jiang et al. 2018; Li et al. 2019; Zhao et al. 2018). Furthermore, the airborne bacteria, as an important component of airborne microbes, depends on the type, range, plant species and crown density of green space (Ren et al. 2012). Urban forest parks are the main areas for people to recreation and healthcare in the daily life (Oh et al. 2017). It is therefore necessary to explore the changing airborne bacteria of different forest communities and related influence factors.

The previous studies on airborne bacterial distribution and concentration have been conducted within the maximum human exposure range, such as residences, school, hospitals, industrial regions, and parks (Chegini et al. 2020; Gao et al. 2018; Guan et al. 2015; Harbizadeh et al. 2019; Hui et al. 2019; Ye et al. 2021). Abundant studies have suggested lower bacterial concentrations outdoors (Hui et al. 2019). Regarding to outdoor air, it has been reported that the amount of bacterial colony in the forests might be 100 times lower than that of urban areas air or rather less (Fang et al. 2007; Huang and Wu 2002; Mu et al. 2020). In addition, Dong et al. (2018) demonstrated that the airborne bacterial content was in ascending order as arboreous forest, shrub forest, herb community. Furthermore, different plant species also significantly impact the ambient bacterial concentrations. Study has shown that the airborne bacterial concentration of needle-leaved trees were higher than broad-leaved trees (Gu et al. 2020). On the other hand, with the increase in altitude or distance, airborne bacterial concentrations vary in one forest community. Lyngwi et al. (2013) pointed out that bacterial concentrations of tropical Eastern Himalaya which decreased with increasing altitudes. A study found that the horizontal change of airborne bacterial concentrations was on descend trend within $15 \mathrm{~m}$ distance of the border of urban green areas, and no significant difference beyond the $15 \mathrm{~m}$ (Ren 2007). The abovementioned studies indicated relatively large changes in airborne bacterial concentration associated with the specific locations, and these changes follow a pattern for each season (spring, summer, autumn and winter) of the year according to region (Gandolfi et al. 2015; Li et al. 2019). In the subtropical cities of China, the bacterial concentrations between spring and winter and temperate climates varied by three and one order of magnitude, respectively (Xie et al. 2019). As airborne bacteria present everywhere in indoor and outdoor environments, the variations of bacterial concentrations could mainly be explained by region and time.

However, recent studies have indicated strong evidence that airborne bacteria can also be affected by environmental factors, such as temperature ( $T$ ), wind speed (WS), relative humidity (RH), PM2.5, PM10, SO 2 (Gao et al. 2015; Jones and Harrison 2004; Li et al. 2019; Li et al. 2021; Ruiz-Gil et al. 2020; Zhong et al. 2016). Airborne bacteria as an important biological component of forest ecosystem, the forest community-transfer of environmental bacteria is more likely affected by the forest microclimate conditions including T, RH, WS (Amini Parsa et al. 2019; Boehnke et al. 2017). The contents of airborne bacteria significantly increased with the air temperature increasing from $10{ }^{\circ} \mathrm{C}$ to $15{ }^{\circ} \mathrm{C}$ in spring (Gu et al. 2020). While a growing number of studies focusing on the dust detaining abilities of different trees were conducted in various environments (Mcdonald et al. 2007; Nowak et al. 2006; Song et al. 2015), there is still a lack of studies that assess the correlation among airborne bacteria, forest community type, meteorological elements and particulate matter in the forest (Guo et al. 2013).

The urban forest park is a place where people often relax and exercise (Meyer et al. 2019). Hence, due to the diverse vegetational species, the complex internal environment and the various ecological function of the urban forest park, it is meaningful to investigate its bacterial air quality. In this study, we provided firsthand information concerning airborne bacteria in an urban forest park. As such, the aim of this study was to investigate the seasonal and temporal variations of airborne bacterial concentration and antimicrobial capacity of different vegetation types in urban green areas, and figure out the driving factors of airborne bacterial concentrations. The research results are of great significance to make decisions of the construction and management of forest healthcare, which would improve human health and well-being by making the urban environment a more pleasant and aesthetic place to live.

\section{Materials And Methods}


This study was conducted in an urban botanical garden $\left(25.78^{\circ} \mathrm{N}, 112.99^{\circ} \mathrm{E}\right)$ located in the western part of Chenzhou City in the southeast of Hunan Province, China (Fig. 1). Nanling botanical garden has a total area of $0.402 \mathrm{~km}^{2}$, and its altitude ranges from 120 to $338 \mathrm{~m}$. It belongs to the subtropical monsoon humid climate zone. The local climate experiences long summers and short winters, and is hot and humid. The annual average temperature is $17.4{ }^{\circ} \mathrm{C}$, and the annual precipitation is $1452.1 \mathrm{~mm}$. The frost-free period is 284 days per year.

There are various types of vegetation, and a total of 6 sampling sites (based on forest community type) were selected, as presented in Table 1 . The blank plots were selected to be in the square (an open space), and had no vegetation. The sampling plots inside the forest which included deciduous broad-leaved community, evergreen broad-leaved community, deciduous needle-leaf community, evergreen coniferous community, mixed needle-leaf and broad-leaved community and uncovered space.

\section{Airborne bacteria collection and analysis}

The ambient air samplings of different forest community types were conducted at $2 \mathrm{~h}$ intervals during the daytime from 8 am to 6 pm in January 2020 (winter), April 2020 (spring), August 2020 (summer), and November 2020 (autumn). Samples from each site during each season had been collected with sunny for at least three consecutive days and there was little rain or cloud cover. Three sampling points were set in every forest plot by the diagonal method.

The airborne bacteria were collected with disposable petri dishes $(90 \times 90 \mathrm{~mm}$, size) using Nutrient Agar (Shengsi Bio Tech, Inc., Shanghai, China) as the culture medium, where microbial partimhcles settlement onto these agar mediums by gravity. Triplicate samples disposable petri dishes from each sampling location, approximately 1.2-1.5 m above ground level (being close to human breathing height), were collected airborne bacteria for 10 min duration. Thus, airborne bacteria emission rates of each forest plot were calculated by averaging 9 values (3 locations $\times 3$ plates). Nutrient Agar was prepared for bacteria by using $33 \mathrm{~g}$ of agar per liter. Mediums were previously prepared and sterilized in the autoclave (YXQ-LS-75S11, Boxun Industry\&Commerce Co. Ltd., ShangHai, China) before pouring it in petri dishes.

After collection, the sampled petri dishes should be inverted and sealed up immediately, then brought back to the laboratory and cultured in a constant temperature incubator (ZXSD-B1270,Zhicheng instrument Corp., ShangHai, China). The bacteria were incubated at $37^{\circ} \mathrm{C}$ for $48 \mathrm{~h}$. The concentrations were expressed as colony-forming units per cubic meter of air $\left(\mathrm{CFU} / \mathrm{m}^{3}\right)$. For each forest community sampling site, the air sampler was always wiped with alcohol between sample collections to avoid cross-contamination. Three field blanks were assessed for every forest community and no field blank samples were positive.

The colonies obtained were expressed as $\mathrm{CFU} / \mathrm{m}^{3}$. The airborne bacterial concentration was calculated by using Eq. (1) (Zhou et al. 2010).

$$
C=\frac{5000 \times N}{A \times t}
$$

In Eq. (1), C (CFU/m $\left.\mathrm{m}^{3}\right)$ is the concentration of bacteria in the air, $\mathrm{N}(\mathrm{CFU})$ is the total number of colonies, $\mathrm{t}(\mathrm{min})$ is the sampling time, and $\mathrm{A}\left(\mathrm{cm}{ }^{2}\right)$ is the petri dish's area.

The bacteriostatic rate expressed as \% were calculated by Eq. (2) (Zhou et al. 2010).

$$
Y=\frac{(E i-E j) \times 100}{E j} \quad(2)
$$

In Eq. (2), $Y(\%)$ is the bacteriostatic rate of the sampling site, $E_{j}\left(C F U / m^{3}\right)$ is the airborne bacterial concentrations of the sampling site of $C K, E_{i}\left(C F U / m^{3}\right)$ is the airborne bacterial concentrations of the sampling site inside the forest.

\section{Environmental factor measurements}

Concurrently, the forest environment, including wind speed (WS), relative humidity (RH), temperature (T), ultraviolet light (UV), negative air ion (NAI) and particulate matter (PM) concentrations [total suspended particles (TSP), PM10, PM2.5, PM1.0] of each forest plot were measured while sampling airborne bacteria. Kestrel Weather Meter (Kestrel 5500, Nielsen-Kellerman Co., USA) was employed to record the T, RH and WS (T: $-29-70{ }^{\circ} \mathrm{C}$ (range), $\pm 0.1^{\circ} \mathrm{C}$ (accuracy); RH: $0-99.9 \%$ (range), $\pm 0.1 \%$ (accuracy); WS: $0-40.0 \mathrm{~m} / \mathrm{s}$ (range), $\pm 0.1 \mathrm{~m} / \mathrm{s}$ (accuracy)). UV was measured by a Dual-channel UV meter with a 254 detector (UV-B, Beijing Shida Photoelectric Technology Ltd., China), $\lambda_{P}$ from 230 to $275 \mathrm{~nm}$, and the measuring range of the detector was $0.1-199.9 \times 10^{3} \mu W / \mathrm{cm}^{2}$, the operating $\mathrm{T}$ and humidity were $0-40{ }^{\circ} \mathrm{C}$ and $85 \% \mathrm{RH}$. NAl concentration was measured by a unified corrected negative ion monitor COM-3200PRO II produced in Japan with an observation range of the detector was $10-1.999 * 10^{9}$ ion/cm3, the operating $\mathrm{T}$ and humidity were $4-40{ }^{\circ} \mathrm{C}$ and $100 \% \mathrm{RH}$. The Turnkey DustMate environment monitor (DUSTMATE, Turnkey Instruments Ltd, UK) was used to measure TSP $\left(0.1 \mu \mathrm{g} / \mathrm{m}^{3}\right.$ accuracy), PM10 (0.1 $\mu \mathrm{g} / \mathrm{m}^{3}$ accuracy), PM2.5 (0.01 $\mu \mathrm{g} / \mathrm{m}^{3}$ accuracy), PM1.0 $\left(0.01 \mu \mathrm{g} / \mathrm{m}^{3}\right.$ accuracy) mass concentration with a range of $0.01-6000 \mu \mathrm{g} / \mathrm{m}^{3}$. All instruments have been calibrated before sampling.

\section{Data analysis}

The data were analysed using Origin 2021 (OriginLab, USA) and SPSS 23.0 (IBM Corp., USA). As the distribution was parametric, one-way ANOVA was used to compare airborne bacterial concentrations among different forest community types and the bacteriostatic rate of forest community typies from the spring to winter. The t-test was used to analyze the significant difference in the comparison of the forest community types for the same season of bacteriostatic rate. In addition, the relationships among bacteria, meteorological factors, and air pollutants were examined using non-parametric Spearman's rank correlation 
method. A multiple linear regression model was used to analyze the effects of several variables (T, RH, WS, UV, NAI, TSP, PM10, PM2.5 and PM1.0) on airborne bacterial concentrations. Statistical significance was defined as $p<0.05$.

\section{Results And Discussion}

\section{Distribution characteristics of airborne bacterial concentration Vegetational variation in airborne bacterial concentration}

The airborne bacterial samples were collected from the five forest communities and an uncovered space environment, and the concentrations of airborne bacteria are illustrated in Fig. 2. Considering the five forest communities, the whole year of airborne bacterial concentrations varied greatly, and from least to highest was $\mathrm{SA}<\mathrm{SM}<\mathrm{SN} \approx \mathrm{SK}<\mathrm{ST}$, the averages were $907 \pm 567,1067 \pm 736,1157 \pm 770,1120 \pm 693$ and $1364 \pm 882 \mathrm{CFU} / \mathrm{m}^{3}$, respectively. The average airborne bacterial concentration of the mixed forest was the least, which was significant lower than that of CK $(p<0.05)$. The two kinds of evergreen forests were found to be less than those of deciduous, and the broad-leaved forests were also found to be less than those of needle-leaved trees. Gu et al. (2020) studied airborne bacterial concentration of three forest communities (Chinese fir (Cunninghamia lanceolate), masson pine (Pinus massoniana) and moso bamboo (Phyllostachys ubescens)) in China, and found that moso bamboo (broad-leaved trees) had lower airborne bacterial concentration than Chinese fir and masson pine (needle-leaved trees), which is similar to our results. The airborne bacterial concentration of CK was the highest with the average of 1658 $\mathrm{CFU} / \mathrm{m}^{3}$. The findings revealed that the average concentration of the airborne bacteria in the urban forest park was lower than the recommended value of the air-quality standard of China ( $<2500 \mathrm{CFU} / \mathrm{m}^{3}$ ) (China, 2002), indicating the range of cleaner to clean. The concentration of airborne bacteria in the urban forest space was less than that found in the studies performed in the Xi'an downtown region $\left(0.83 \pm 0.45^{\star} 10^{5}\right.$ cells $\left./ \mathrm{m}^{3}\right)(B a i$ et al. 2021$)$, or the outside of Nanjing Forestry University (4596 CFU/m³) (Liu 2006), but was higher than the $87 \mathrm{CFU} / \mathrm{m}^{3}$ measured in a remote forest mountain in China (Gu et al. 2020). Different studies have found that the airborne bacterial concentration significantly differed across different areas, which may be because of different environmental conditions, the difference in the nature of activities and specific sources (Maki et al. 2017; Zhai et al. 2018). This demonstrates that people living in urban environments are exposed to a higher bacterial concentration compared to rural inhabitants.

\section{Temporal variability in airborne bacterial concentrations}

In this study, temporal variations of airborne bacterial concentration of all tested forest communities during the sampling period over the four seasons are shown in Fig. 3.

From the perspective of the whole year, the seasonal average change trend of airborne bacterial concentration of urban forest in spring and summer were higher than these in autumn and winter, and summer was the highest concentration over seasons. Additionally, the airborne bacterial concentrations of all sampling forest communities showed a similar trend, that is, a greater concentration in the late morning and early afternoon than in the early morning and late afternoon or at noon. Interestingly, while the trend is generally M-shaped, it is sometimes not obvious, this may be due to external factors, such as human, plants and animals activities. This suggests that the concentration of airborne bacteria increased with increasing activities from human or other living organism, which consistent with the hypothesis of biological circadian rhythms (Heo et al. 2017). What's more, in winter, the airborne bacterial concentrations of all forest sampling sites were higher than CK at noon, especially significantly higher in $\mathrm{SA}(\mathrm{p}<0.01)$, and increased as temperature increased between $12: 00$ and 16:00. The airborne bacteria daily bottom hours were at the sampling time of 18:00 in spring, CK, SN, SM, ST, and SK, the concentrations of airborne bacteria were $594 \pm 264,838 \pm 105,419 \pm 182,384 \pm 121$, and $594 \pm 61 \mathrm{CFU} / \mathrm{m}^{3}$, respectively. And that the airborne bacterial concentrations of SA was lowest among these six sampling sites, especially at 14:00 $\left(105 \pm 182 \mathrm{CFU} / \mathrm{m}^{3}\right)$. In summer, the concentration of airborne bacteria of CK $\left(1240 \pm 151 \mathrm{CFU} / \mathrm{m}^{3}\right)$, SN $\left(594 \pm 320 \mathrm{CFU} / \mathrm{m}^{3}\right)$ and SA $\left(769 \pm 337 \mathrm{CFU} / \mathrm{m}^{3}\right)$ at 14:00 were lower than other sampling times, which showed the total bacterial concentrations decreased as temperature increased, and there was significant reduction of the airborne bacterial concentrations of the forest community types of SN, SM, ST, and SA at 10 am $(p<0.01)$. In autumn, the concentration of airborne bacteria of SN $\left(454 \pm 160 \mathrm{CFU} / \mathrm{m}^{3}\right)$ and ST $\left(804 \pm 242 \mathrm{CFU} / \mathrm{m}^{3}\right)$ were lowest at 8 am, and CK $(559 \pm$ $\left.242 \mathrm{CFU} / \mathrm{m}^{3}\right), \mathrm{SM}\left(349 \pm 121 \mathrm{CFU} / \mathrm{m}^{3}\right)$ and SK $\left(349 \pm 264 \mathrm{CFU} / \mathrm{m}^{3}\right)$ were at 18:00, which means the airborne bacterial concentrations of the deciduous forests of SN and ST were higher than these in evergreen forests of SM and SK, especially significantly higher at 16:00 $(p<0.05)$.

Previous studies are in agreement with the result that reported seasonal and hourly variation in airborne bacterial concentrations (Hu et al. 2020). It was observed that airborne bacteria showed a distinct seasonal pattern with a significantly higher concentrations in the summer than other seasons. The shift of meteorological parameters over the four seasons may partially explain the seasonal variations in bacterial concentration (Leyronas and Nicot 2013). The weather of Chenzhou city is a subtropical monsoon climate with cold and less rain in winter, and hot and more rain in summer. In general, summer with high temperature and humidity (70-80\%) is considered as a conducive season for microbial growth and reproduction (Genitsaris et al. 2017; Smets et al. 2016), which would lead to a higher bacterial concentrations in the air in summer. Due to the fact that the environment of the urban forest belongs to a special outdoor space, another possible reason for the high bacterial concentration of urban forest in summer and that low in winter, some plants bloomed in spring and summer (Jackson and Denney 2011; Redford and Fierer 2009), and withered or grew slowly in autumn and winter (Kozdrój et al. 2019). In addition, compared to the deciduous forests of SN and ST, the more leaves and the higher volatile organic chemicals concentrations (Aydin et al. 2014) were in evergreen forests of SM and SK, which may be the reason for the less airborne bacterial concentrations in autumn and winter. There is a possible explanation for these temporal-spatial disparities that the relative contributions of the site-specific biological sources at different times. Visitors, soil and vegetation may be the main sources of airborne bacteria at the urban forest park (Xie et al. 2018a). Hence, diverse environmental conditions and different environmental parameters around different sampling sites led to different seasonal concentration variations of airborne bacteria (Zhai et al. 2018).

\section{Bacteriostasis of different forest communities}


Large vegetated land covers such as forests emit substantial amounts of BVOCs, and approximately 1700 BVOCs emitted by 90 different plant families were defined in the literature (Knudsen and Gershenzon, 2006), which could lead to a harsher environment for airborne bacteria (Gao et al. 2005). In the present study, the bacteriostatic rates of the five forest community types were significant variable in each sampling sites in the same season, nevertheless, no significant effects varied in the broad-leaved forest community and green forest community over the four seasons (Fig. 4). In winter, the bacteriostatic rate of SA (mixed forest community) not only had significant differences with other sampling sites $(\mathrm{p}<0.05)$, but also $14.3 \%$ higher than CK. In the spring, the concentration of airborne bacteria increased with tree sprouting and organisms revival, five sampling sites with the rate of SA (84.28\%), SK (46.34\%), ST (38.08\%), SM (20.73\%), and SN (14.63\%) were lower than that in CK $(p<0.05)$, which indicate that there was significant variation of the bacteriostatic of coniferous forest and mixed forest. In summer, the bacteriostatic ability of forest was ordered as: SN $(-51.01 \%)>$ SA $(-43.76 \%)>$ SM $(-35.48 \%)>$ ST $(-13.69 \%)>$ SK $(-8.72 \%)>$ CK with no significant difference $(p>0.05)$. The bacteriostatic rate of SN, SM, ST, SK and SA were $-6.67 \%,-53.85 \%, 30.77 \%,-24.1 \%$ and $-36.41 \%$ in autumn, respectively, with significant differences between SM and SA, and that the airborne bacterial concentration of ST was extremely higher than CK. As we know, BVOCs are able to decontaminate the air by inhibiting the growth and reproduction of airborne pathogens. It has been reported that BVOCs, such as limonene, a-pinene, $\beta$-pinene, and myrcene, inhibited the growth of bacteria, and that various conifer species emitted more BVOCs and a stronger bacteriostasis in terms of BVOCs (Aydin et al. 2014; Gao et al. 2005; Hong and Jin 2001). Whereas our results were not the same, the bacteriostasis and airdecontaminating effects of BVOCs were needed to further discuss in terms of their habitat factor. Thus, vegetative species had significant or extremely significant effects on airborne bacterial concentrations.

\section{Factors influencing the bacterial concentration in different forest communities}

\section{Correlations between airbome bacterial concentration and influencing factors}

During the whole sampling period, the environmental factors (meteorological elements, UV, NAI, PM and airborne bacteria) of air samples from the 6 sampling sites were observed (Table 2). Spearman's correlation coefficients of these parameters with the measured bacterial concentrations are presented in Fig. 5.

From the field data, Spearman's correlation analysis showed that forest community type was negatively correlated with the environmental factors except for $\mathrm{RH}$ and NAI, and there were significant correlations between forest community type and WS, T, UV, PM1.0, PM10, TSP, and airborne bacterial concentration (p囚 0.05). Many related studies have reported that there were a positive correlation between forest and RH or NAl (Wang et al. 2020a; Wang et al. 2020b), and a negative correlation between forest and T, UV or airborne particulate matter (Wang et al. 2019). Whereas there were no significant correlations between forest community types and RH, NAl, or PM2.5 in this study ( $>0.05)$. In addition, meteorological conditions, such as T, RH, and WS, varied with the season, which led to significant correlations between temporal factors and environmental factors (pष0.05). On the other hand, airborne bacterial concentration was found to be significantly positively correlated with WS, T, UV, NAI and TSP, especially for the season (p凶0.05), and significantly negatively correlated with PM2.5 and PM1.0 (pष0.05). Several previous studies also have shown similar results, which indicated that there were correlations between airborne bacterial concentrations and environmental parameters (Frankel et al. 2012). What's more, seasonal variation has a significant impact on negative or positive correlations.

Spearman's correlation coefficients of environmental parameters with the measured airborne bacterial concentrations in every season are depicted in Table 3. There were seasonal differences between airborne bacterial concentration and the forest community type. Over the four seasons, the forest community type was found to be significantly negatively correlated with the airborne bacterial concentration in spring and summer ( $\mathrm{p} \otimes 0.01$ ), and the correlation gradually tended to fade in autumn, and transformed positively in winter (pष0.01).

Seasonal variations were found in the correlation between airborne bacterial concentration and environmental factors, and different environmental factors affecting airborne bacterial concentration were disparate in each season. In terms of season, the airborne bacterial concentration in the spring was susceptible to more environmental factors than others seasons. There were also seasonal differences existed in the correlation between airborne bacterial concentration and a single environmental factor. For example, the WS was found to be significant positively correlated with the airborne bacterial concentration in spring (p区 0.05) and autumn (pष0.05), but no correlations in summer and winter. Genitsaris et al. (2017) found that no statistically significant correlation between WS and the concentration of the airborne bacteria. Meanwhile, a positive correlation was also detected between airborne bacterial concentration and RH in spring and summer (though not significant), and a negative correlation in autumn ( $\mathrm{p} \otimes 0.01$ ) and winter, and the possible reasons were that the more frequent rain in spring and summer, whereas the less rain days in autumn and winter. The increase in air humidity would inhibit raising dusts and promote bacterial concentration (Almaguer et al. 2014). Furthermore, UV was as well as found to be positively correlated with airborne bacterial concentration in spring (p凶0.01), summer and autumn ( $\mathrm{p} \otimes 0.05$ ), but negatively in winter. In forest, leaves of vegetation could block UV, which may have contributed to universally increase airborne bacterial survival, and leaves of some deciduous plants here fall in winter could lead to a significant negative influence on the culturability of airborne microorganisms by solar radiation intensity (Tang 2009). In addition, the correlation between airborne bacterial concentration and T was weak over the four seasons. While Genitsaris et al. (2017) reported that air temperature had a significant correlation with bacterial concentration. In this study, the average sample temperature $\left(16.8 \pm 4.8^{\circ} \mathrm{C}\right)$ of the forest in winter was less than $24{ }^{\circ} \mathrm{C}$, below which the cultivation of airborne bacteria is thought to universally decrease (Tang 2009).

Likewise, TSP was found to be positively correlated with airborne bacterial concentration in all seasons, particularly significant in the spring (p区0.01) and summer (pष0.05). The effects of PM2.5 and PM1.0 matter on airborne bacterial concentration were not remarkable, but the correlations between them were positive in spring and summer, and negative in autumn and winter. Guo et al. (2013) found that the airborne bacterial concentration had a significant positive correlation with TSP, but had a significant negative correlation with PM2.5 and PM1.0 in Beijing urban forest. Ren (Ren 2007) discovered that the airborne bacterial concentration had a significant positive correlation with TSP, but had a non-significant relationship with PM2.5 and PM1.0 in Beijing green space. These results are similar to our study. However, other studies in urban outdoor space of China, such as Jinan (Wei et al. 2020), Xi'an (Xie et al. 2018b), Beijing (Li et al. 2018), and Hangzhou (Liu et al. 2018), suggested that the bacterial concentrations were gradually increased as the particulate matter concentration 
concentration went up from clean to moderately polluted, which are not consistent with our results. Maybe for the reason that the particle matters (PM2.5 and PM1.0) were more easily affected by other factors such as forest microclimate and even had negative correlations with airborne bacteria. Besides, published research (Guo et al. 2013) on the biological effects of NAl revealed that NAI can inhibit the growth of bacteria, but the correlation between NAI and airborne bacterial concentration was weak in this study.

In summary, airborne bacterial concentration is controlled by multiple and variable abiotic and biotic factors, which among others may include the temporal variability, diverse vegetation types, forest micro meteorological, particulate matter concentrations, and human activities (Dong et al. 2018; Guo et al.

2013; Zhai et al. 2018), which not independent, rather, there are interactions.

\section{Multiple linear regression of airborne bacterial concentration and environmental parameters}

To further understand the effects of various parameters on airborne bacterial concentration, forest community type, T, WS, UV, NAI, TSP, PM2.5 and PM1.0 as independent variables, and airborne bacterial concentration as the dependent variable was used to establish a multiple linear regression model to analyse the cause of changes in airborne bacterial concentrations. The multiple linear regression model for airborne bacterial concentrations is shown as Equation (3).

Bacterial concentration $=1679.773+375.292 \mathrm{WS}+1.651 \mathrm{UV}+0.470 \mathrm{NAl}+2.678 \mathrm{TSP}-7.570 \mathrm{PM} 2.5 \quad$ Equation (3)

Analytical results show that the $\mathrm{R}^{2}$ was $0.178(\mathrm{p}=0.000)$ for multiple linear regression modes, thus, the model reached a significant level and had statistical significance. According to Equation (3), the WS and UV have a significantly positive effect on the airborne bacterial concentrations ( $p<0.05)$. Li et al. (2021) confirmed the importance of WS and UV for bacterial concentrations. Strong wind could bring in exogenous bacteria or dilute the concentration of local bacteria (Zhong et al. 2016). When the results among every season were compared, more sunshine, strong solar radiation and ultraviolet light were found in summer causing the airborne bacterial concentrations in summer to be higher than that in other seasons (Zhai et al. 2018). In addition, Equation (3) also shows that NAI and TSP significantly positively affect airborne bacterial concentrations $(p<0.05)$, and PM2.5 significantly negatively affects airborne bacterial concentrations $(p<0.05)$. This study found that with an increasing vegetation coverage, the lower bacterial concentration was. Since more vegetation coverage of evergreen broad-leaved forest and mixed forest and the TSP and PM2.5 concentrations are lower in the broad-leaved forest than coniferous forest, and evergreen forest than deciduous forest, there is a lower airborne bacterial concentration in SM and SA (Table 1 and Fig. 2). The result of this study is similar to the result of section 3.3.1 that meteorological parameters have a great effect on airborne bacterial concentrations, and the impact of meteorological factors on airborne bacterial concentration was greater than that of the airborne particulates, and Zhen et al. (2017) illustrated meteorological factors had more impact on airborne bacterial communities than air pollutants. However, forest community type, T and PM1.0 had no significant effect on airborne bacterial concentrations ( $\mathrm{p} \otimes 0.05)$. Gu et al. (2020) found that temperature played a key role in the concentration of airborne bacterial.

\section{Conclusions}

Field measurements of bacterial air quality in five forest communities were carried out in this study to identify the spatial and temporal variation distribution characteristics of airborne bacterial concentration, as well as to examine the influencing factors. The findings revealed that the bacterial concentrations of all the five communities of forest were the range of cleaner to clean levels. The airborne bacterial concentrations from least to highest appeared in the following order: SA (mixed forest), SM and SK (evergreen forests)>SN and ST (deciduous forests), SM and SN (broad-leaved forests) >ST and SK (needle-leaved trees). Highest bacterial concentrations in summer, and relatively low in winter, and the daily airborne bacterial concentrations of sampling forests showed an $\mathrm{M}$ shaped trend. Spearman's correlation showed that significant correlations among forest community types, temporal factors and the environmental factors. In addition, the airborne bacterial concentrations in the spring were susceptible to more environmental factors than others' seasons. When a multiple linear regression model of airborne bacterial concentration in the forest, including the WS, UV, NAI, TSP and PM2.5 was established, the model showed statistical significance $(p=0.000)$. Our findings indicate that the mixed forest is the best selection for improving air quality and public healthcare, the regulation of urban forest communities could improve urban forest services by decreasing the efficiency of airborne bacterial concentration and airborne particulate matter.

\section{Declarations}

Acknowledgements We thank Shaohua Deng, Qiang Cui, Yuze Xv, Yuming Li, Haixia Zhang, PingXiu Wu, Xi Wang and Haizhou Huang from Chenzhou Institute of Forestry for the help of air sampling.

Authors' contributions Methodology, investigation, validation, formal analysis, data curation, writing-original draft preparation-review and editing: Zhenni Liao. Conceptualization, visualization, review and editing: HuiJuan Xu. Conceptualization, visualization, review and editing: Jiaojiao Ma. Investigation, data curation, visualization, supervision: Maojuan Li. Investigation, resources: Caisheng He. Data curation: Qiongrui Zhang. Conceptualization, visualization, review and editing, resources: Song-jun Xu.

Ethics approval and consent to participate Not applicable. This manuscript does not contain any studies with human participants or animals performed by any of the authors.

Consent for publication Not applicable. This manuscript does not contain any individual person's data in any form.

Availability of data and materials Not applicable.

Competing interests The authors declare that they have no conflict of interest.

Funding Not applicable. 


\section{References}

1. Almaguer M, Aira MJ, Rodríguez-Rajo FJ, Rojas TI (2014) Temporal dynamics of airborne fungi in Havana (Cuba) during dry and rainy seasons: influence of meteorological parameters. International Journal of Biometeorology 58(7):1459-1470. https://doi.org/10.1007/s00484-013-0748-6

2. Amini Parsa V, Salehi E, Yavari A R, van Bodegom P M (2019) Analyzing temporal changes in urban forest structure and the effect on air quality improvement. Sustainable Cities and Society 48:101548. https://doi.org/10.1016/j.scs.2019.101548

3. Aydin YM, Yaman B, Koca H, Dasdemir O, Kara M, Altiok H, Dumanoglu Y, Bayram A, Tolunay D, Odabasi M, Elbir T (2014) Biogenic volatile organic compound (BVOC) emissions from forested areas in Turkey: determination of specific emission rates for thirty-one tree species. Sci. Total Environ. 490:239-53. https://doi.org/10.1016/j.scitotenv.2014.04.132

4. Bai W, Li Y, Xie W, Ma T, Hou J, Zeng X (2021) Vertical variations in the concentration and community structure of airborne microbes in PM2.5. Sci. Total Environ. 760:143396. https://doi.org/10.1016/j.scitotenv.2020.143396

5. Bielinis E, Takayama N, Boiko S, Omelan A, Bielinis L (2018) The effect of winter forest bathing on psychological relaxation of young Polish adults. Urban Forestry \& Urban Greening 29:276-283. https://doi.org/10.1016/j.ufug.2017.12.006

6. Boehnke D, Gebhardt R, Petney T, Norra S (2017) On the complexity of measuring forests microclimate and interpreting its relevance in habitat ecology: the example of Ixodes ricinus ticks. Parasit Vectors 10(1):549. https://doi.org/10.1186/s13071-017-2498-5

7. Broeckx BJ, Coopman F, Verhoeven GE, De Keulenaer S, De Meester E, Bavegems V, Smets P, Van Ryssen B, Van Nieuwerburgh F, Deforce D (2016) Toward the most ideal case-control design with related and unrelated dogs in whole-exome sequencing studies. Anim. Genet. 47(2):200-7.

https://doi.org/10.1111/age.12400

8. Chegini F M, Baghani A N, Hassanvand M S, Sorooshian A, Golbaz S, Bakhtiari R, Ashouri A, Joubani M N, Alimohammadi M (2020) Indoor and outdoor airborne bacterial and fungal air quality in kindergartens: Seasonal distribution, genera, levels, and factors influencing their concentration. Build. Environ. 175:106690. https://doi.org/10.1016/j.buildenv.2020.106690

9. China SC (2002) Indoor air quality standard (GB/T18883). Beijing: China Zhijian Publishing House (in Chinese)

10. Dong S, Wu L, Yu J, Zhang Z, Zhao Y, Jia C (2018) Study on Airborne Bacteria Content Variation in Typical Forest Types of Taihang Mountain. Meteorological and Environmental Sciences 41(1):62-68. https://doi.org/10.16765 / j. cnki.1673-7148.2018. 01. 008 (in Chinese)

11. Fang Z, Ouyang Z, Hua Z, Wang X, Hu L (2007) Culturable airborne bacteria in outdoor environments in Beijing, China. Microb. Ecol. 54(3):487-496. https://doi.org/10.1007/s00248-007-9216-3

12. Frankel M, Beko G, Timm M, Gustavsen S, Hansen EW, Madsen AM (2012) Seasonal Variations of Indoor Microbial Exposures and Their Relation to Temperature, Relative Humidity, and Air Exchange Rate. Applied Environmental Microbiology 78(23):8289-97. https://doi.org/10.1128/AEM.02069-12

13. Gandolfi I, Bertolini V, Bestetti G, Ambrosini R, Innocente E, Rampazzo G, Papacchini M, Franzetti A (2015) Spatio-temporal variability of airborne bacterial communities and their correlation with particulate matter chemical composition across two urban areas. Applied Microbiology Biotechnology 99(11):4867-4877. https://doi.org/10.1007/s00253-014-6348-5

14. Gao M, Jia R, Qiu T, Han M, Song Y, Wang X (2015) Seasonal size distribution of airborne culturable bacteria and fungi and preliminary estimation of their deposition in human lungs during non-haze and haze days. Atmos. Environ. 118:203-210. https://doi.org/10.1016/j.atmosenv.2015.08.004

15. Gao XL, Shao MF, Wang Q, Wang LT, Fang WY, Ouyang F, Li J (2018) Airborne microbial communities in the atmospheric environment of urban hospitals in China. Journal of Hazardous Materials 349(5):10-17. https://doi.org/10.1016/j.jhazmat.2018.01.043

16. Gao Y, Jin YJ, Hai-Dong LI, Chen HJ (2005) Volatile Organic Compounds and Their Roles in Bacteriostasis in Five Conifer Species. Journal of Integrative Plant Biology 47(004):499-507. https://doi.org/10.1111/j.1744-7909.2005.00081.x

17. Genitsaris S, Stefanidou N, Katsiapi M, Kormas K A, Sommer U, Moustaka-Gouni M (2017) Variability of airborne bacteria in an urban Mediterranean area (Thessaloniki, Greece). Atmos. Environ. 157:101-110. https://doi.org/10.1016/j.atmosenv.2017.03.018

18. Gu X, Wang X, Li C, Li J, Cui Y, Hu J, Liang H (2020) Airborne microbial content and antimicrobial capacity in three typical forest communities in Jinyun Mountain, Chongqing. Chin. J. Appl. Environ. Biol. https://doi.org/10.19675/j.cnki.1006-687x.2020.02017 (in Chinese)

19. Guan D, Guo C, Li Y, Lv H, Yu X (2015) Study on the Concentration and Distribution of the Airborne Bacteria in Indoor Air in the Lecture Theatres at Tianjin Chengjian University, China. Procedia Engineering 121:33-36. https://doi.org/10.1016/j.proeng.2015.08.1015 (in Chinese)

20. Guo E, Wang C, Qie G, Cai Y (2013) Relationships between the factors reflecting ecological health function of urban forests. Chinese Journal of Ecology 32(11):2893-2903. https://doi.org/10.13292/j.1000-4890.2013.0444 (in Chinese)

21. Harbizadeh A, Mirzaee SA, Khosravi AD, Shoushtari FS, Goodarzi H, Alavi N, Ankali KA, Rad HD, Maleki H, Goudarzi G (2019) Indoor and outdoor airborne bacterial air quality in day-care centers (DCCs) in greater Ahvaz, Iran. Atmos. Environ. 216:116927. https://doi.org/10.1016/j.atmosenv.2019.116927

22. Heo KJ, Lim CE, Kim HB, Lee BU (2017) Effects of human activities on concentrations of culturable bioaerosols in indoor air environments. Journal of Aerosol Science 104:58-65. https://doi.org/10.1016/j.jaerosci.2016.11.008

23. Hong R, Jin YJ (2001) The Advances of Research on Aromachology in Japan. World Forestry Research 14:61-66. https://doi.org/10.13348/j.cnki.sjlyyj.2001.03.010

24. Hu Z, Liu H, Zhang H, Zhang X, Zhou M, Lou L, Zheng P, Xi C, Hu B (2020) Temporal discrepancy of airborne total bacteria and pathogenic bacteria between day and night. Environ. Res. 186:109540. https://doi.org/10.1016/j.envres.2020.109540

25. Huang J, Wu C (2002) Distribution of the microorganism groups in the air of forest area. Sci. Silvae Sin. 38(2):173-176 (in Chinese) 
26. Hui N, Parajuli A, Puhakka R, Gronroos M, Roslund MI, Vari HK, Selonen VAO, Yan G, Siter N, Nurminen N, Oikarinen S, Laitinen OH, Rajaniemi J, Hyoty H, Sinkkonen A (2019) Temporal variation in indoor transfer of dirt-associated environmental bacteria in agricultural and urban areas. Environ. Int. 132:105069. https://doi.org/10.1016/j.envint.2019.105069

27. Jackson CR, Denney WC (2011) Annual and seasonal variation in the phyllosphere bacterial community associated with leaves of the southern Magnolia (Magnolia grandiflora). Microb. Ecol. 61(1):113-122. https://doi.org/10.1007/s00248-010-9742-2

28. Jiang Y, Ji X, Wang Y (2018) Study on the correlationbetween ambient air microorganism and PM10 in Lianyungang. Pollution Control Technology 31(4):8-10 (in Chinese)

29. Jones AM, Harrison RM (2004) The effects of meteorological factors on atmospheric bioaerosol concentrations-a review. Sci. Total Environ. 326(1/3):151-180. https://doi.org/10.1016/j.scitotenv.2003.11.021

30. Joung D, Kim G, Choi Y, Lim H, Park S, Woo J M, Park B J (2015) The Prefrontal Cortex Activity and Psychological Effects of Viewing Forest Landscapes in Autumn Season. Int J Environ Res Public Health 12(7):7235-43. https://doi.org/10.3390/ijerph120707235

31. Knudsen JT, Gershenzon J (2006) The chemistry diversity of floral scent. In: Dudareva N, Pichersky E (ed) Biology of floral scent. CRC Press, Boca Raton, Florida, pp 27-52

32. Kozdrój J, Frączek K, Ropek D (2019) Assessment of bioaerosols in indoor air of glasshouses located in a botanical garden. Building and Environment 166. https://doi.org/10.1016/j.buildenv.2019.106436

33. Leyronas C, Nicot PC (2013) Monitoring viable airborne inoculum of Botrytis cinerea in the South-East of France over 3 years: relation with climatic parameters and the origin of air masses. Aerobiologia 29(2):291-299. https://doi.org/10.1007/s10453-012-9280-0

34. Li H, Zhou XY, Yang XR, Zhu YG, Hong YW, Su JQ (2019) Spatial and seasonal variation of the airborne microbiome in a rapidly developing city of China. Sci. Total Environ. 665:61-68. https://doi.org/10.1016/j.scitotenv.2019.01.367

35. Li P, Li L, Wang Y, Zheng T, Liu J (2021) Characterization, factors, and UV reduction of airborne bacteria in a rural wastewater treatment station. Sci. Total Environ. 751:141811. https://doi.org/10.1016/j.scitotenv.2020.141811

36. Li W, Yang J, Zhang D, Li B, Wang E, Yuan H (2018) Concentration and Community of Airborne Bacteria in Response to Cyclical Haze Events During the Fall and Midwinter in Beijing, China. Frontiers in microbiology. https://doi.org/10.3389/fmicb.2018.01741

37. Liu H, Zhang X, Zhang H, Yao X, Zhou M, Wang J, He Z, Zhang H, Lou L, Mao W (2018) Effect of air pollution on the total bacteria and pathogenic bacteria in different sizes of particulate matter. Environ. Pollut. 233:483-493. https://doi.org/10.1016/j.envpol.2017.10.070

38. Liu Y (2006) The Studies on Bacteriostat and Eeffcts of Filtering Dust of Urban Forestsin Nanjing City. Dissertation, Nanjing Forestry University (in Chinese)

39. Lyngwi NA, Koijam K, Sharma D, Joshi SRJRDBT (2013) Cultivable bacterial diversity along the altitudinal zonation and vegetation range of tropical Eastern Himalaya. Rev. Biol. Trop. 61(1):467-490. https://doi.org/10.15517/rbt.v61i1.11141

40. Maki T, Hara K, Iwata A, Lee K C, Kawai K, Kai K, Kobayashi F, Pointing S B, Archer S, Hasegawa H (2017) Variations in airborne bacterial communities at high altitudes over the Noto Peninsula (Japan) in response to Asian dust events. Atmospheric Chemistry Physics 17(19):1-32.

https://doi.org/10.5194/acp-17-11877-2017

41. Mcdonald AG, Bealey WJ, Fowler D, Dragosits U, Skiba U, Smith RI, Donovan RG, Brett HE, Hewitt C N, Nemitz E (2007) Quantifying the effect of urban tree planting on concentrations and depositions of PM10 in two UK conurbations. Atmos. Environ. 41(38):8455-8467.

https://doi.org/10.1016/j.atmosenv.2007.07.025

42. Meyer MA, Rathmann J, Schulz C (2019) Spatially-explicit mapping of forest benefits and analysis of motivations for everyday-life's visitors on forest pathways in urban and rural contexts. Landscape Urban Plann. 185:83-95. https://doi.org/10.1016/j.landurbplan.2019.01.007

43. Mu F, Li Y, Lu R, Qi Y, Xie W, Bai W (2020) Source identification of airborne bacteria in the mountainous area and the urban areas. Atmospheric Research 231:104676. https://doi.org/10.1016/j.atmosres.2019.104676

44. Nowak DJ, Crane DE, Stevens JC (2006) Air pollution removal by urban trees and shrubs in the United States. Urban Forestry Urban Greening 4(3-4):115123. https://doi.org/10.1016/j.ufug.2006.01.007

45. Ochiai H, Ikei H, Song C, Kobayashi M, Miura T, Kagawa T, Li Q, Kumeda S, Imai M, Miyazaki Y (2015) Physiological and Psychological Effects of a Forest Therapy Program on Middle-Aged Females. Int J Environ Res Public Health 12(12):15222-32. https://doi.org/10.3390/ijerph121214984

46. Oh B, Lee KJ, Zaslawski C, Yeung A, Rosenthal D, Larkey L, Back M (2017) Health and well-being benefits of spending time in forests: systematic review. Environ Health Prev Med 22(1):71. https://doi.org/10.1186/s12199-017-0677-9

47. Redford AJ, Fierer N (2009) Bacterial Succession on the Leaf Surface: A Novel System for Studying Successional Dynamics. Microbial Ecology 58(1):189198. https://doi.org/10.1007/s00248-009-9495-y

48. Ren Q, Li Jie, cheng W (2012) Effects of three-dimensional greenness of urban forest on airborne microorganism and particulate matter concentration. Practical Forestry Technology 11:3-6. https://doi.org/10.13456/j.cnki.lykt.2012.11.009 (in Chinese)

49. Ren QW (2007) Study on Airborne Microbes Concentration Change of Urban Greenlands in Beijing City. Dissertation, university of Beijing Forestry.

50. Ruiz-Gil T, Acuna JJ, Fujiyoshi S, Tanaka D, Noda J, Maruyama F, Jorquera MA (2020) Airborne bacterial communities of outdoor environments and their associated influencing factors. Environ. Int. 145:106156. https://doi.org/10.1016/j.envint.2020.106156

51. Smets W, Moretti S, Denys S, Lebeer S (2016) Airborne bacteria in the atmosphere: Presence, purpose, and potential. Atmos. Environ. 139:214-221. https://doi.org/10.1016/j.atmosenv.2016.05.038

52. Song C, Ikei H, Miyazaki Y (2017) Sustained effects of a forest therapy program on the blood pressure of office workers. Urban Forestry \& Urban Greening 27:246-252. https://doi.org/10.1016/j.ufug.2017.08.015 
53. Song Y, Maher BA, Li F, Wang X, Sun X, Zhang H (2015) Particulate matter deposited on leaf of five evergreen species in Beijing, China: Source identification and size distribution. Atmos. Environ. 105:53-60. https://doi.org/10.1016/j.atmosenv.2015.01.032

54. Tang JW (2009) The effect of environmental parameters on the survival of airborne infectious agents. Journal of The Royal Society Interface 6(Suppl_6):S737-S746. https://doi.org/10.1098/rsif.2009.0227.focus

55. Wang H, Wang B, Niu X, Song Q, Li M, Luo Y, Liang L, Du P, Peng W (2020a) Study on the change of negative air ion concentration and its influencing factors at different spatio-temporal scales. Global Ecology and Conservation 23:e01008. https://doi.org/10.1016/j.gecco.2020.e01008

56. Wang W, Zhang B, Zhou W, Lv H, Xiao L, Wang H, Du H, He X (2019) The effect of urbanization gradients and forest types on microclimatic regulation by trees, in association with climate, tree sizes and species compositions in Harbin city, northeastern China. Urban Ecosystems 22(2):367-384. https://doi.org/10.1007/s11252-019-0823-9

57. Wang Y, Ni Z, Wu D, Fan C, Lu J, Xia B (2020b) Factors influencing the concentration of negative air ions during the year in forests and urban green spaces of the Dapeng Peninsula in Shenzhen,China. Journal of Forestry Research 31(06):490-500. https://doi.org/10.1007/s11676-019-01047-z

58. Wei M, Liu H, Chen J, Xu C, Li J, Xu P, Sun Z (2020) Effects of aerosol pollution on PM2.5-associated bacteria in typical inland and coastal cities of northern China during the winter heating season. Environ. Pollut. 262:114188. https://doi.org/10.1016/j.envpol.2020.114188

59. Xie J, Jin L, He T, Chen B, Luo X, Feng B, Huang W, Li J, Fu P, Li X (2019) Bacteria and Antibiotic Resistance Genes (ARGs) in PM2.5 from China: Implications for Human Exposure. Environmental Science Technology 53(5):963-972. https://doi.org/10.1021/acs.est.8b04630

60. Xie J, Jin L, Luo X, Zhao Z, Li X (2018a) Seasonal Disparities in Airborne Bacteria and Associated Antibiotic Resistance Genes in PM2.5 between Urban and Rural Sites. Environmental Science \& Technology Letters 5(2):74-79. https://doi.org/10.1021/acs.estlett.7b00561

61. Xie Z, Fan C, Lu R, Liu P, Wang B, Du S, Jin C, Deng S, Li Y (2018b) Characteristics of ambient bioaerosols during haze episodes in China: A review. Environ. Pollut. 243(PB):1930-1942. https://doi.org/10.1016/j.envpol.2018.09.051

62. Ye J, Qian H, Zhang J, Sun F, Zhuge Y, Zheng X, Cao G (2021) Concentrations and size-resolved I/O ratios of household airborne bacteria and fungi in Nanjing, southeast China. Sci. Total Environ. 774:145559. https://doi.org/10.1016/j.scitotenv.2021.145559

63. Yu CP, Hsieh H (2020) Beyond restorative benefits: Evaluating the effect of forest therapy on creativity. Urban Forestry \& Urban Greening 51. https://doi.org/10.1016/j.ufug.2020.126670

64. Zhai Y, Li X, Wang T, Bei C, Zeng G (2018) A review on airborne microorganisms in particulate matters: Composition, characteristics and influence factors. Environ. Int. 113:74-90. https://doi.org/10.1016/j.envint.2018.01.007

65. Zhao Y, Shi CQ, Xv DF, Kang XL, Liu XY, Z TN (2018) Variations in Negative Air lon Concentrations Associated with Different Vegetation Types and Influencing Factors in Chongli District. For. Res. 31( 3):127 -135. https://doi.org/10.13275/j.cnki.lykxyj. 2018. 03. 017 (in Chinese)

66. Zhen Q, Deng Y, Wang Y, Wang X, Zhang H, Sun X, Ouyang Z (2017) Meteorological factors had more impact on airborne bacterial communities than air pollutants. Sci. Total Environ. 601-602:703-712. https://doi.org/10.1016/j.scitotenv.2017.05.049

67. Zhong X, Qi J, Li H, Dong L, Gao D (2016) Seasonal distribution of microbial activity in bioaerosols in the outdoor environment of the Qingdao coastal region. Atmospheric Environment 140(9):506-513. https://doi.org/10.1016/j.atmosenv.2016.06.034

68. Zhou D-h, Ma S-f, Wang S-d, Jiang L-I, Zhang R-m, Hou P (2010) Inhibition against airborne microbes in four stand types. Journal of Zhejiang Forestry College 27(1):93-98

\section{Tables}

Table 1 Outline of sampling sites

\begin{tabular}{|c|c|c|c|c|c|c|c|}
\hline $\begin{array}{l}\text { Sampling } \\
\text { site }\end{array}$ & $\begin{array}{l}\text { Forest community } \\
\text { type }\end{array}$ & $\begin{array}{l}\text { Plant } \\
\text { species }\end{array}$ & $\begin{array}{l}\text { Forest } \\
\text { height } \\
\nabla \mathrm{m} \nabla\end{array}$ & $\begin{array}{l}\text { Mean branch height } \\
\bigotimes \mathrm{m} \rrbracket\end{array}$ & $\begin{array}{l}\text { DBH } \\
\text { 『cm } 『\end{array}$ & Canopy density & $\begin{array}{l}\text { Average } \\
\text { age }\end{array}$ \\
\hline CK & Blank & None & - & - & - & - & - \\
\hline SN & $\begin{array}{l}\text { Deciduous broad-leaved } \\
\text { forest }\end{array}$ & Nyssa sinensis & 13 & 5.0 & 27 & 0.7 & $45 a$ \\
\hline SM & $\begin{array}{l}\text { Evergreen broad-leaved } \\
\text { forest }\end{array}$ & Magnolia & 15 & 3.0 & 28 & 0.8 & $45 a$ \\
\hline ST & $\begin{array}{l}\text { Deciduous coniferous } \\
\text { forest }\end{array}$ & $\begin{array}{l}\text { Taxodium ascendens } \\
\text { Brongn }\end{array}$ & 15 & 3.7 & 26 & 0.6 & $45 a$ \\
\hline SK & Evergreen coniferous forest & Keteleeria pubescens & 13 & 4.0 & 16 & 0.7 & $45 a$ \\
\hline SA & Mixed forest & $\begin{array}{l}\text { Azalea and Pinus } \\
\text { Massoniana }\end{array}$ & $\begin{array}{l}0.9-2.2 \\
16\end{array}$ & $\begin{array}{l}0.6 \\
8.0\end{array}$ & $\begin{array}{l}0.5-7 \\
24\end{array}$ & 0.9 & $38 a$ \\
\hline
\end{tabular}


Table 2 Environment parameters of the different forest communities in Nanling botanical garden

\begin{tabular}{|c|c|c|c|c|c|c|c|c|c|c|c|c|c|c|c|c|}
\hline & CK & & & SM & & & ST & & & SK & & & SN & & & SA \\
\hline & Mean & Max & Min & Mean & Max & Min & Mean & Max & Min & Mean & Max & Min & Mean & Max & Min & $\mathrm{Me}$ \\
\hline$W(m / s)$ & $\begin{array}{l}0.6 \\
\pm 0.6\end{array}$ & 3.2 & 0.0 & $\begin{array}{l}0.2 \pm \\
0.2\end{array}$ & 0.8 & 0.0 & $\begin{array}{l}0.2 \pm \\
0.4\end{array}$ & 2.3 & 0.0 & $\begin{array}{l}0.3 \pm \\
0.3\end{array}$ & 1.2 & 0.0 & $\begin{array}{l}0.3 \pm \\
0.4\end{array}$ & 1.7 & 0.0 & $\begin{array}{l}0.2 \\
0.3\end{array}$ \\
\hline $\mathrm{T}\left({ }^{\circ} \mathrm{C}\right)$ & $\begin{array}{l}27.3 \pm \\
6.9\end{array}$ & 38.6 & 7.8 & $\begin{array}{l}25.5 \pm \\
6.5\end{array}$ & 35.9 & 7.9 & $\begin{array}{l}24.9 \\
\pm 6.3\end{array}$ & 33.8 & 7.8 & $\begin{array}{l}25.0 \\
\pm 6.1\end{array}$ & 33.8 & 8.2 & $\begin{array}{l}25.3 \\
\pm 6.1\end{array}$ & 34.9 & 8.9 & $\begin{array}{l}23 . \\
\pm 6\end{array}$ \\
\hline $\mathrm{H}(\%)$ & $\begin{array}{l}54 \pm \\
15\end{array}$ & 86 & 31 & $58 \pm 14$ & 87 & 35 & $\begin{array}{l}59 \pm \\
12\end{array}$ & 83 & 35 & $\begin{array}{l}61 \\
\pm 14\end{array}$ & 89 & 34 & $\begin{array}{l}56 \pm \\
12\end{array}$ & 97 & 32 & $\begin{array}{l}59 \\
17\end{array}$ \\
\hline $\begin{array}{l}\text { UV } \\
\left(\mu \mathrm{W} / \mathrm{cm}^{2}\right)\end{array}$ & $\begin{array}{l}228 \pm \\
273\end{array}$ & 949 & 0.00 & $\begin{array}{l}18 \pm \\
34\end{array}$ & 219 & 0 & $\begin{array}{l}37 \pm \\
43\end{array}$ & 303 & 0 & $9 \pm 11$ & 47 & 0 & $\begin{array}{l}73 \pm \\
88\end{array}$ & 489 & 0 & $\begin{array}{l}53 \\
97\end{array}$ \\
\hline $\begin{array}{l}\mathrm{NAI} \\
\text { (ions/cm³) }\end{array}$ & $\begin{array}{l}312 \pm \\
239\end{array}$ & 818 & 0 & $\begin{array}{l}695 \pm \\
506\end{array}$ & 2133 & 0 & $\begin{array}{l}805 \pm \\
649\end{array}$ & 3093 & 0 & $\begin{array}{l}778 \pm \\
598\end{array}$ & 2288 & 0 & $\begin{array}{l}586 \pm \\
396\end{array}$ & 1788 & 0 & $\begin{array}{l}53 \\
67 !\end{array}$ \\
\hline $\begin{array}{l}\text { PM1.0 } \\
\left(\mu \mathrm{g} / \mathrm{m}^{3}\right)\end{array}$ & $\begin{array}{l}9.09 \pm \\
7.09\end{array}$ & 45.19 & 3.17 & $\begin{array}{l}8.72 \pm \\
6.46\end{array}$ & 33.77 & 3.13 & $\begin{array}{l}7.12 \\
\pm \\
6.60\end{array}$ & 35.47 & 1.51 & $\begin{array}{l}7.67 \\
\pm \\
8.46\end{array}$ & 39.03 & 1.48 & $\begin{array}{l}8.48 \\
\pm \\
5.56\end{array}$ & 31.78 & 2.87 & $\begin{array}{l}7.6 \\
\pm \\
8.2\end{array}$ \\
\hline $\begin{array}{l}\text { PM2.5 } \\
\left(\mu \mathrm{g} / \mathrm{m}^{3}\right)\end{array}$ & $\begin{array}{l}29.54 \\
\pm 40.88\end{array}$ & 334.52 & 6.90 & $\begin{array}{l}28.13 \\
\pm 20.05\end{array}$ & 93.20 & 12.09 & $\begin{array}{l}23.99 \\
\pm \\
20.75\end{array}$ & 108.34 & 6.16 & $\begin{array}{l}24.17 \\
\pm \\
23.27\end{array}$ & 111.78 & 5.74 & $\begin{array}{l}28.19 \\
\pm \\
18.96\end{array}$ & 92.80 & 11.46 & $\begin{array}{l}23 . \\
\pm \\
21 .\end{array}$ \\
\hline $\begin{array}{l}\text { PM10 } \\
\left(\mu \mathrm{g} / \mathrm{m}^{3}\right)\end{array}$ & $\begin{array}{l}70.5 \pm \\
26.7\end{array}$ & 165.7 & 19.3 & $\begin{array}{l}59.3 \pm \\
33.8\end{array}$ & 254.1 & 11.6 & $\begin{array}{l}58.1 \\
\pm \\
24.1\end{array}$ & 117.0 & 13.8 & $\begin{array}{l}55.7 \\
\pm \\
28.7\end{array}$ & 173.3 & 14.7 & $\begin{array}{l}56.9 \\
\pm \\
26.2\end{array}$ & 114.9 & 14.2 & $\begin{array}{l}45 . \\
\pm \\
28 .\end{array}$ \\
\hline $\begin{array}{l}\text { TSP } \\
\left(\mu \mathrm{g} / \mathrm{m}^{3}\right)\end{array}$ & $\begin{array}{l}150.4 \\
\pm 81.6\end{array}$ & 381.7 & 25.8 & $\begin{array}{l}114.8 \\
\pm 79.8\end{array}$ & 389.0 & 27.1 & $\begin{array}{l}121.6 \\
\pm \\
68.1\end{array}$ & 319.0 & 7.3 & $\begin{array}{l}105.3 \\
\pm \\
51.8\end{array}$ & 271.1 & 16.3 & $\begin{array}{l}115.2 \\
\pm \\
65.7\end{array}$ & 276.5 & 16.9 & $\begin{array}{l}86 . \\
\pm \\
51 .\end{array}$ \\
\hline
\end{tabular}

Note: Number of collected air samples during the study period: 432 samples.

Table 3 Seasonal variation in the correlations between airborne bacterial concentration and environmental factors

\begin{tabular}{|lllll|}
\hline & Spring & Summer & Autumn & Winter \\
\hline FCT & $-0.382 \mathrm{a}$ & $-.391 \mathrm{a}$ & -0.092 & $0.242 \mathrm{a}$ \\
WS & $0.326 \mathrm{a}$ & -0.030 & $0.247 \mathrm{~b}$ & 0.039 \\
\hline T & 0.071 & -0.075 & 0.146 & -0.138 \\
\hline RH & 0.076 & 0.043 & $-0.307 \mathrm{a}$ & -0.098 \\
UV & $0.449 \mathrm{a}$ & 0.056 & $0.218 \mathrm{~b}$ & -0.112 \\
\hline NAI & 0.134 & -0.060 & -0.078 & $-0.247 \mathrm{a}$ \\
\hline PM1.0 & 0.106 & 0.094 & -0.157 & $-0.189 \mathrm{~b}$ \\
PM2.5 & 0.029 & 0.207 & -0.134 & $-0.202 \mathrm{~b}$ \\
\hline PM10 & $0.395 \mathrm{a}$ & $0.200 \mathrm{~b}$ & -0.035 & 0.041 \\
\hline TSP & $0.417 \mathrm{a}$ & $0.216 \mathrm{~b}$ & 0.036 & 0.048 \\
\hline
\end{tabular}

Note: a indicates significance at the 0.01 level.

b indicates significance at the 0.05 level.

\section{Figures}




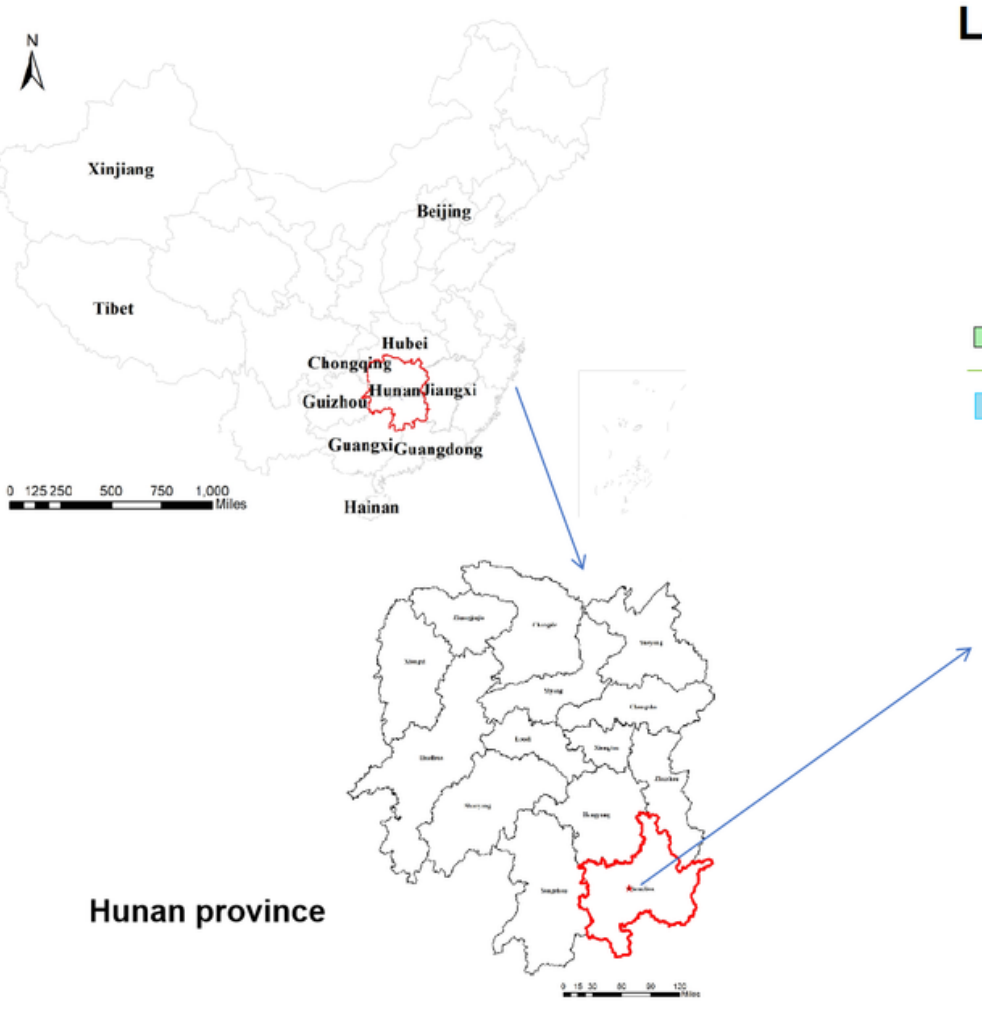

\section{Legend}

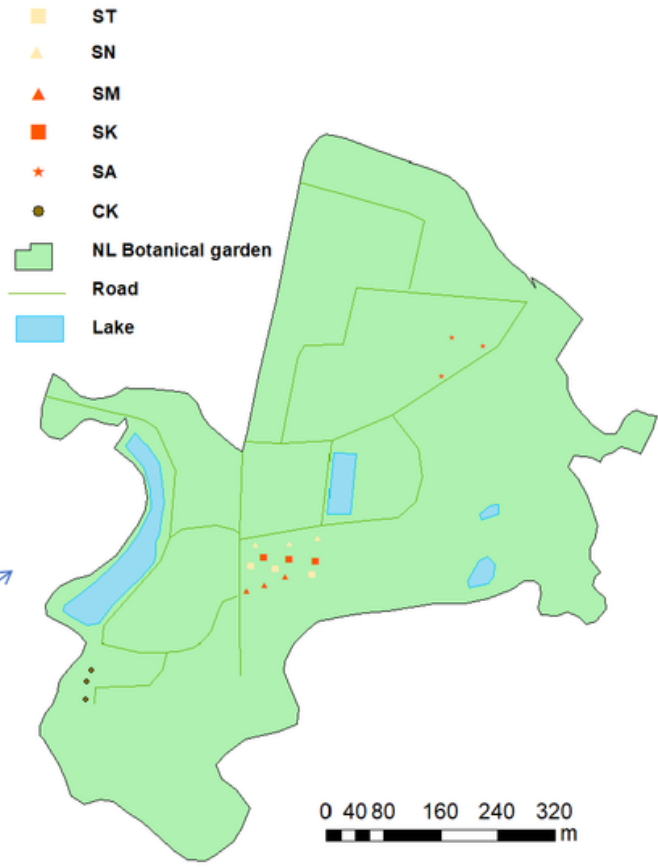

Nanling botanical garden

Figure 1

Location of the Nanling botanical garden 


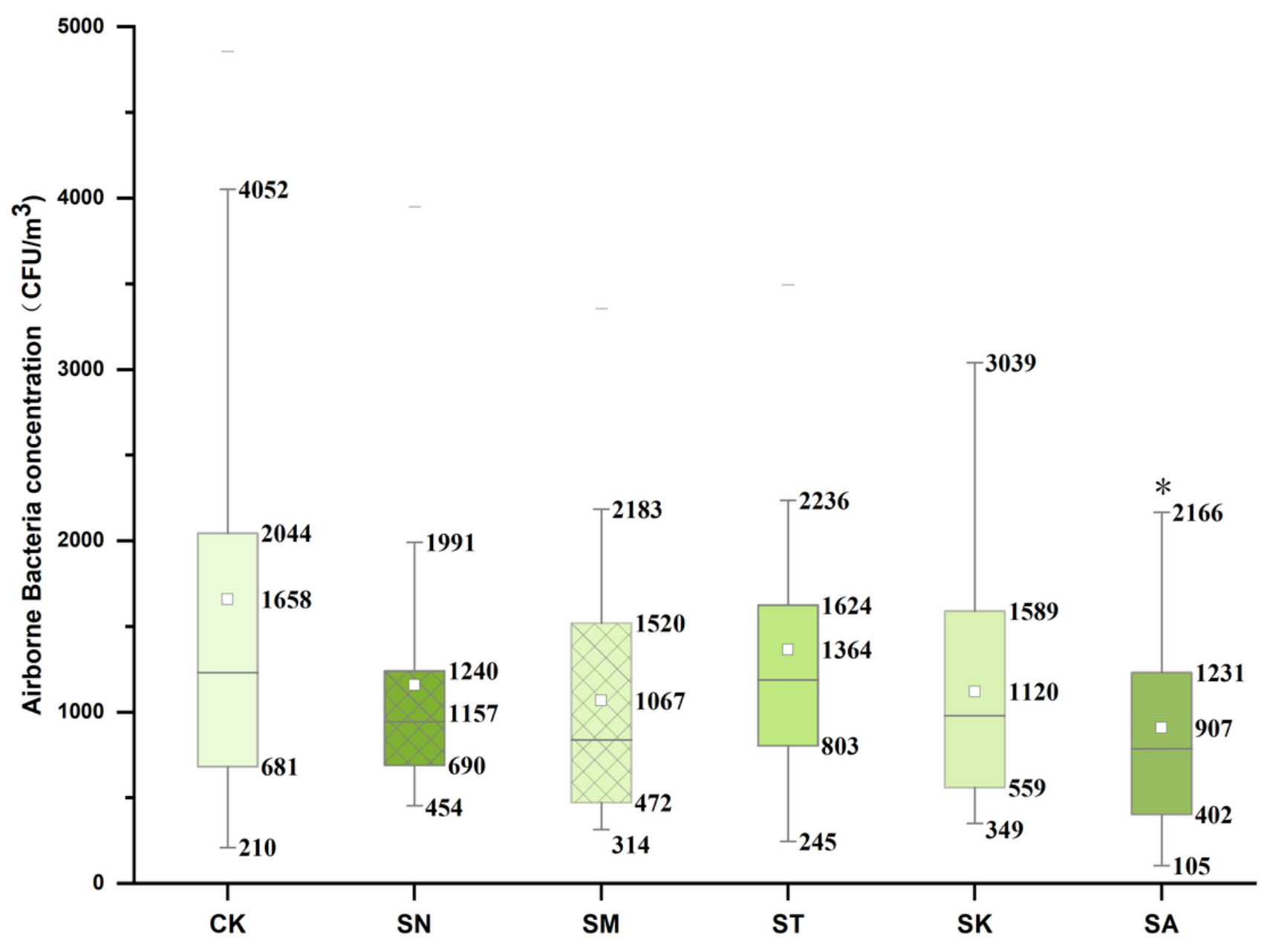

Figure 2

Box plot comparing airborne bacterial concentrations in the different sampling forest sites Note: The box frames represent the upper and lower quartiles, the line represents the median, the whiskers denote the range, and “ $\square$ " represents the mean. " " indicates a statistically significant difference between CK concentrations. 


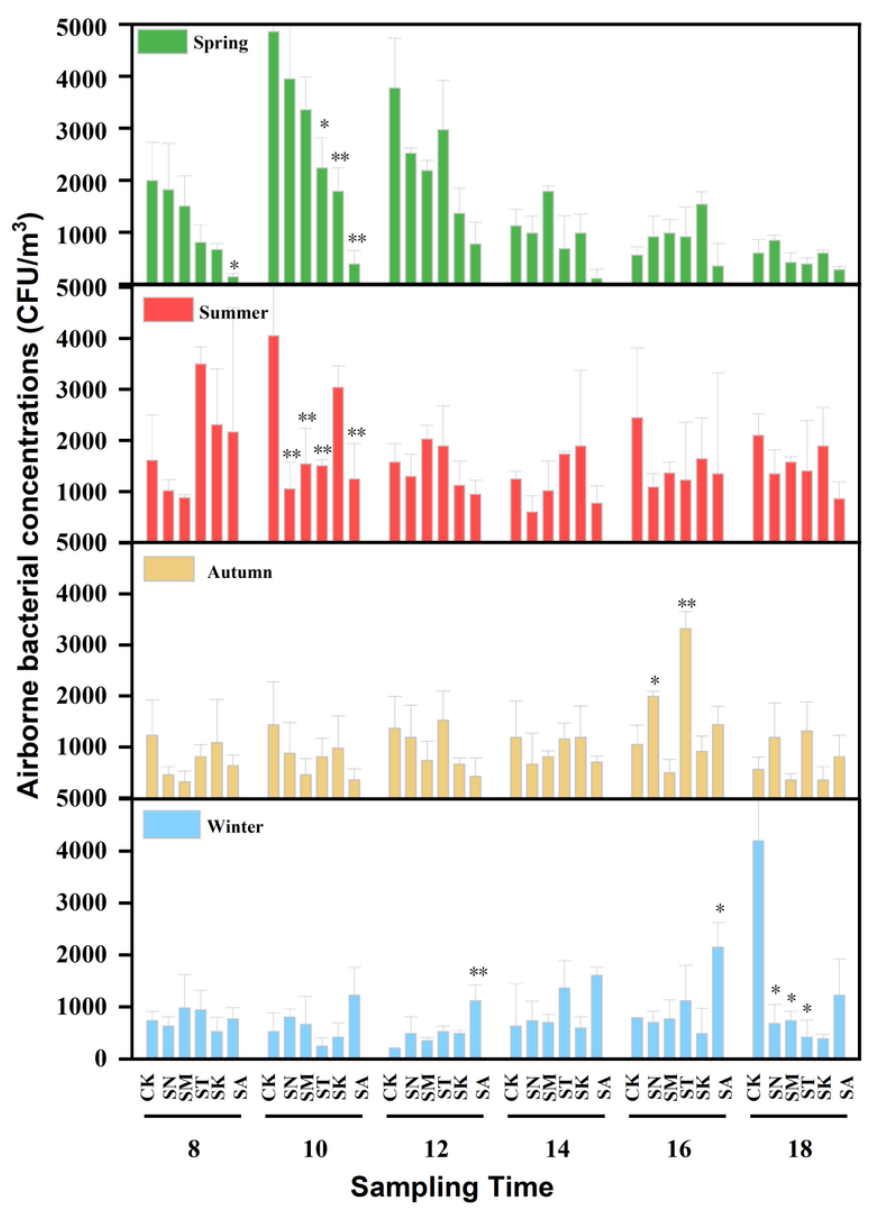

Figure 3

Concentration of airborne bacteria in different forests at temporal variation Note: Data are presented as mean \pm SE $(n=9)$. “*” indicates a statistical significance $(p<0.05)$ among different forest community types (SN, SM, ST, SK, SA and CK) within the same sampling period. 


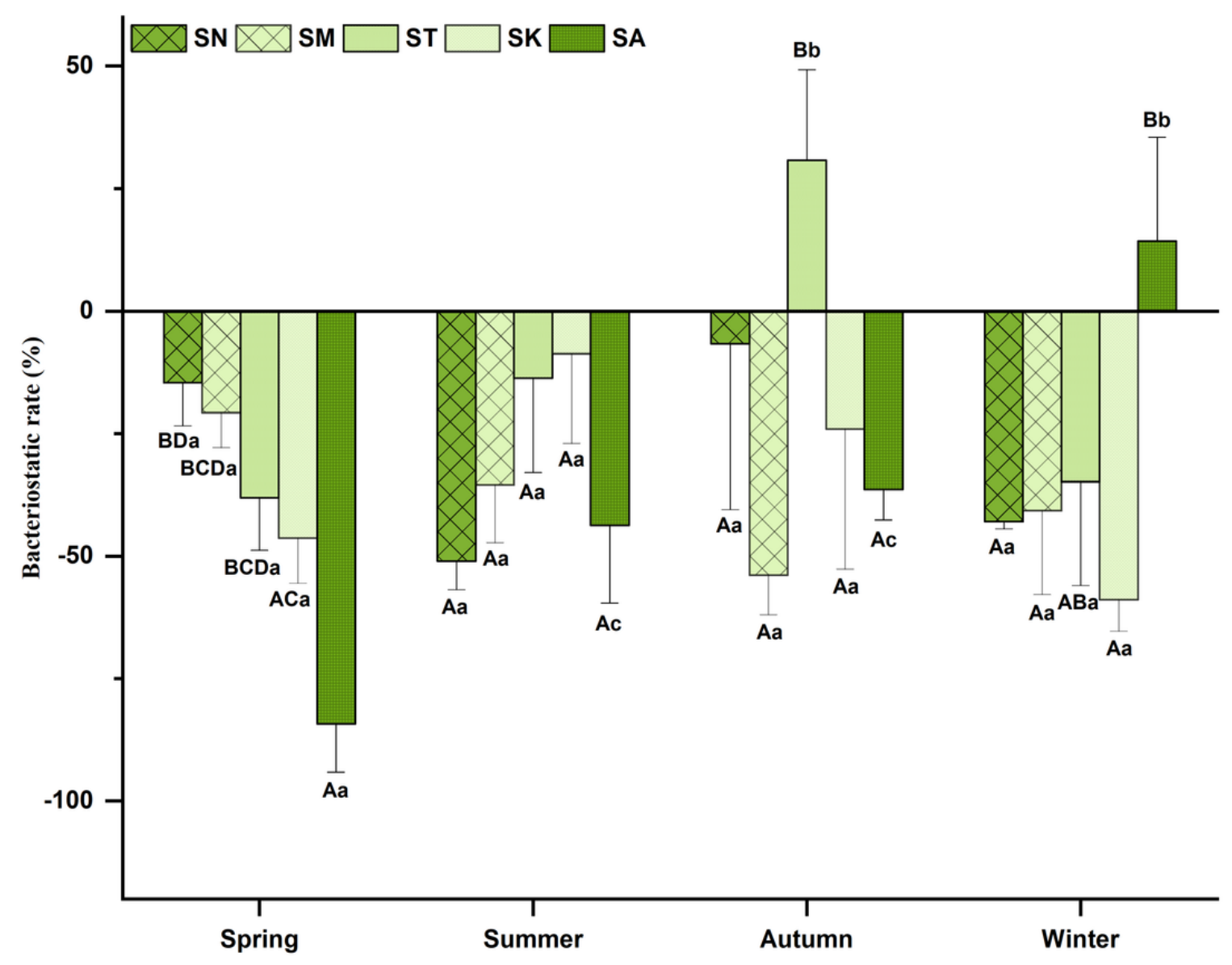

Figure 4

Bacteriostatic rate of different forest community types in different seasons Note: Data are presented as mean $\pm S E(n=54)$. Capital letters represent statistical significances $(p<0.05)$ between different forest community types (SN, SM, ST, SK, SA and CK) within the same season, and lowercase letters represent statistical significances $(p<0.05)$ between different seasons (spring, summer, autumn and winter) within one forest type. 


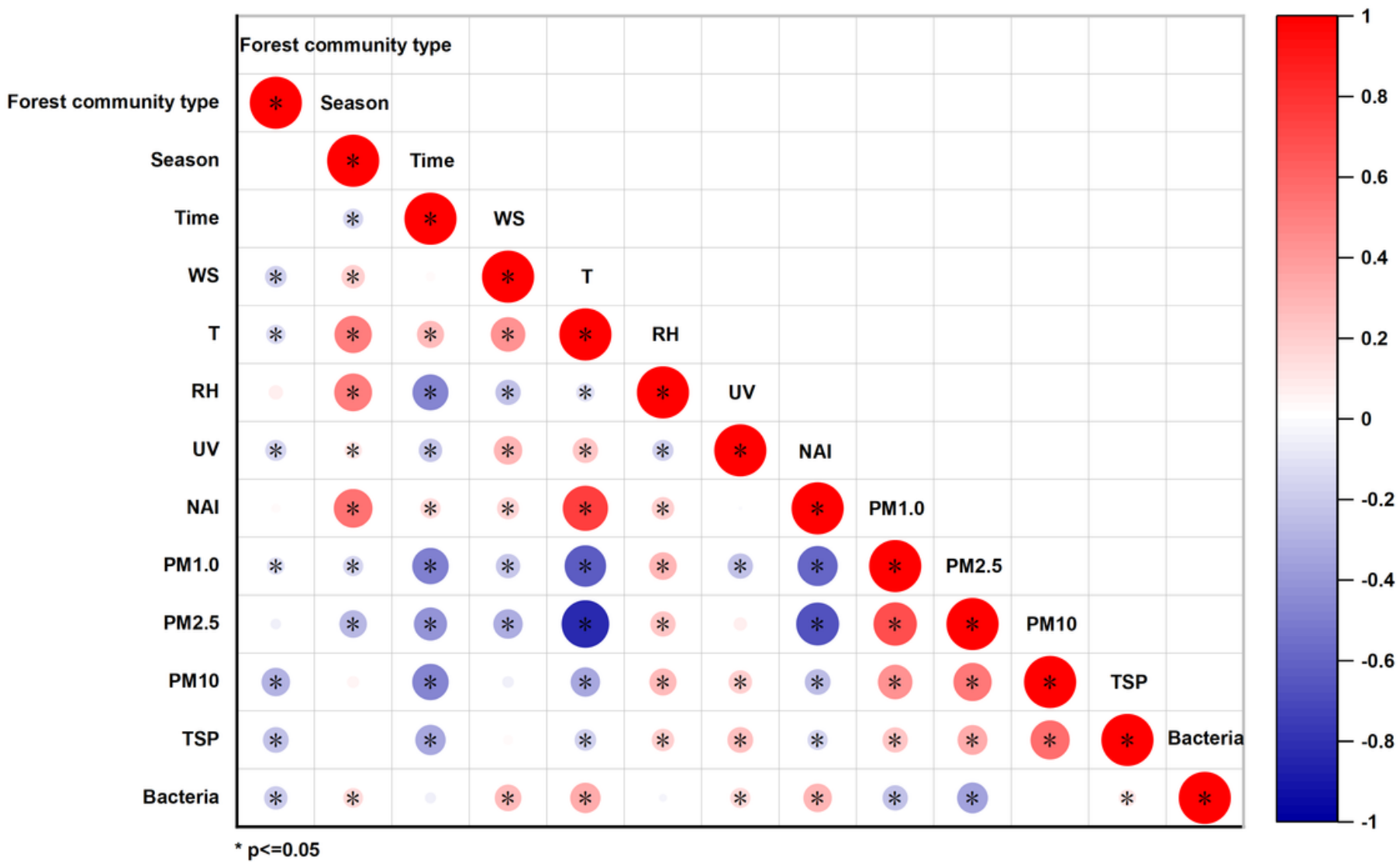

Figure 5

Effects of the forest community type and temporal on forest environmental factors by Spearman's correlation analysis Note: Color intensity on the right represents the value of the correlation coefficient. The figure shows the correlation between forest spatio-temporal and environmental factors with a warm tone indicating positive correlation and cool indicating negative correlation. The darker the color, the bigger the circle, the greater the correlation. * means $\mathrm{p} \leq$ 0.05 , significant mark.

\section{Supplementary Files}

This is a list of supplementary files associated with this preprint. Click to download.

- Supplementdata.docx 